\title{
The taxation of privately owned forest land in Canada: A review of the taxation systems in all ten provinces
}

\author{
by Tony Rotherham ${ }^{1}$
}

\begin{abstract}
Canada has 400 million ha of forest land. Only 25 million ha (5\%) is in private ownership. This private forest land is generally divided in two categories: 450000 private woodlots covering about 15 million ha in the settled regions of Canada and about 5 million ha in larger blocks owned by pension funds, investors, and forest products companies. The private woodlots are subject to municipal or provincial property taxes. The provinces use several approaches to determine the level of tax to be paid. In some cases, the tax system is used to provide an incentive to manage the land. The property tax system offers a policy tool to encourage active management of the land and help ensure a healthy, diverse, and productive forest that contributes forest-related ecological goods and services to the community as well as timber to the local economy.

It is in the long-term interests of rural communities that land remains in production and that forested land is managed to maintain the forest in a healthy condition and produce both forest-related environmental goods and services and timber to support the rural economy. A well-designed property tax structure based on incentives that is accepted as fair and is supported by taxpayers can help to achieve these objectives. The survey of provincial property tax systems shows several approaches to the application of property tax systems on forest lands.

Property tax systems applied to forest land that are based on incentives to actively manage the land and are coupled with financial assistance for tree planting on idle land offer simple and practical ways to keep rural land in production. This is particularly true of marginal/sub-marginal land that has been cleared but is no longer used for agricultural production. Incentives help to ensure that forested land is managed to maintain the forest in a healthy condition and produce forest-related environmental goods and services (EG\&S) as well as timber to support the rural economy.
\end{abstract}

Keywords: privately owned forest land, taxation systems, provinces

\section{RÉSUMÉ}

Le Canada comporte 400 millions d'hectares de terrains forestiers. À peine 25 millions d'hectares (5\%) sont en propriété privée. Ces terrains boisés privés se répartissent en deux catégories : 450000 boisés privés qui couvrent 15 millions d'ha dans les régions développées du Canada et environ 5 millions d'hectares sous forme de grands blocs de forêts détenus par des fonds de pension, des investisseurs et des corporations de produits forestiers. Les boisés privés sont sujets aux taxes foncières municipales ou provinciales. Les provinces ont diverses approches pour établir le taux de taxation à payer. Dans certains cas, elles utilisent le système de taxation comme levier pour favoriser la mise en valeur du territoire. Le système de taxation foncière peut donc constituer un instrument de politique pour dynamiser laménagement du territoire et s'assurer d'avoir une forêt saine, diversifiée et productive qui offre des biens et services environnementaux nécessaires à la communauté tout en fournissant du bois à l'économie locale.

À long terme, les communautés rurales ont tout intérêt à s'assurer que leur territoire demeure productif et qu’on aménage la forêt pour la maintenir en santé et quelles produisent à la fois des biens et services environnementaux ainsi que le bois au bénéfice de léconomie rurale. Pour ce faire, il faut pouvoir compter sur un bon système de taxation foncière tenant compte d'un juste niveau d'incitatifs et qui obtient l'appui des contribuables. L'examen des systèmes de taxes foncières provinciaux montre qu'il existe différentes approches pour l’application des taxes foncières au territoire forestier

Les systèmes de taxes foncières sur le territoire forestier conçus pour encourager laménagement dynamique du territoire et jumelés à de l'aide financière pour reboiser les terres en jachère constituent un moyen simple et commode de maintenir le territoire rural productif. Cela vaut en particulier pour les territoires marginaux ou semi-marginaux qui ont été déboisés et désertés par la suite par la production agricole. Les incitatifs permettent d’assurer un aménagement du territoire forestier qui gardera la forêt en santé et lui permettra de produire les biens et services environnementaux (EG\&S) de même que le bois nécessaire au bien-être de léconomie rurale.

Mots-clés : boisés privés, systèmes fiscaux, provinces

${ }^{1}$ Forestry Consultant, Box 3583, Knowlton, Quebec, J0E 1V0; e-mail: trotherham@sympatico.ca 


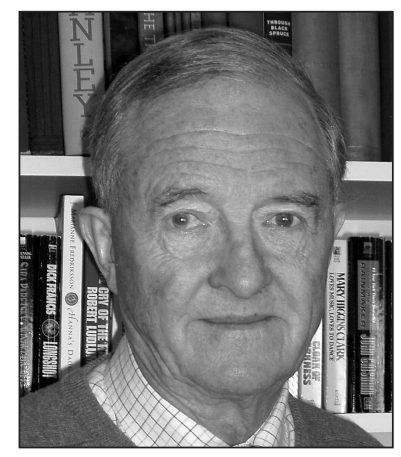

Tony Rotherham

\section{Introduction}

It is estimated that 188 million ha (47\%) of Canada's 400 million ha forest is actively managed for timber production. Approximately 163 million ha $(87 \%)$ of the 188 million ha is publicly owned (by provincial governments) and produces about $80 \%$ of the national timber supply.

Approximately 24.3 million ha $(13 \%)$ of the 188 million ha under active management is in private ownership and produces about $20 \%$ of the national timber supply (Table 1). This is a much smaller proportion than in most industrialized countries. In the USA, approximately $75 \%$ of forest land is in private ownership. Private forest land is found throughout the southern regions of Canada on soils that are generally more productive than the soils in the vast northern tracts of publicly owned forest. These private forests are usually divided into two categories:

- Private Woodlots are associated with areas that were settled and cleared for agriculture during the period 1700-1900. These woodlots cover approximately 19-20 million ha and are owned by an estimated 450000 landowners; the average size is $40 \mathrm{ha}$. These forest lands produce about $14 \%$ of the national timber supply.

- Private Industrial Forest Land covers an estimated 4.5 to 5 million ha. Much of this category is part of the legacy of the railroad construction era, 1850-1900. In the recent past this land was mainly owned by forest products companies but is now owned by a diverse group of investors, including public and private pension funds, foundations, groups of investors, private companies, as well as forest products companies. These forest lands produce about $6 \%$ of the national timber supply.

Together these two categories of private forest land produce about $20 \%$ of the national wood supply - from $13 \%$ of the forest land base under active management.

\section{A brief historical snapshot of rural land use}

Large areas of private land in rural Canada are going out of production. These lands were settled during the period 1700 to 1900 . Settlers were allocated areas of land under the condition that they build houses and clear land for farming. If they fulfilled these obligations they received title to the land. The areas with good soil were cleared for agriculture. Other areas were left in forest. Many of these settlers' homesteads were located in areas with poor soils, lots of stones and difficult topography. In some cases lands not taken up by homesteaders were retained in large blocks of forested land and later sold to lumber companies. The practice of agriculture on these marginal soils (Land Capability for Agriculture Class 4, 5 \& 6) will generally not meet the socio-economic expectations of present landowners. Agriculture is being abandoned on these marginal/sub-marginal soils and the cleared land reverts to forest.

Economists with the federal Department of Agriculture estimate that 5-7 million ha of Canada's 67 million ha of agricultural land are marginal/sub-marginal for agriculture and

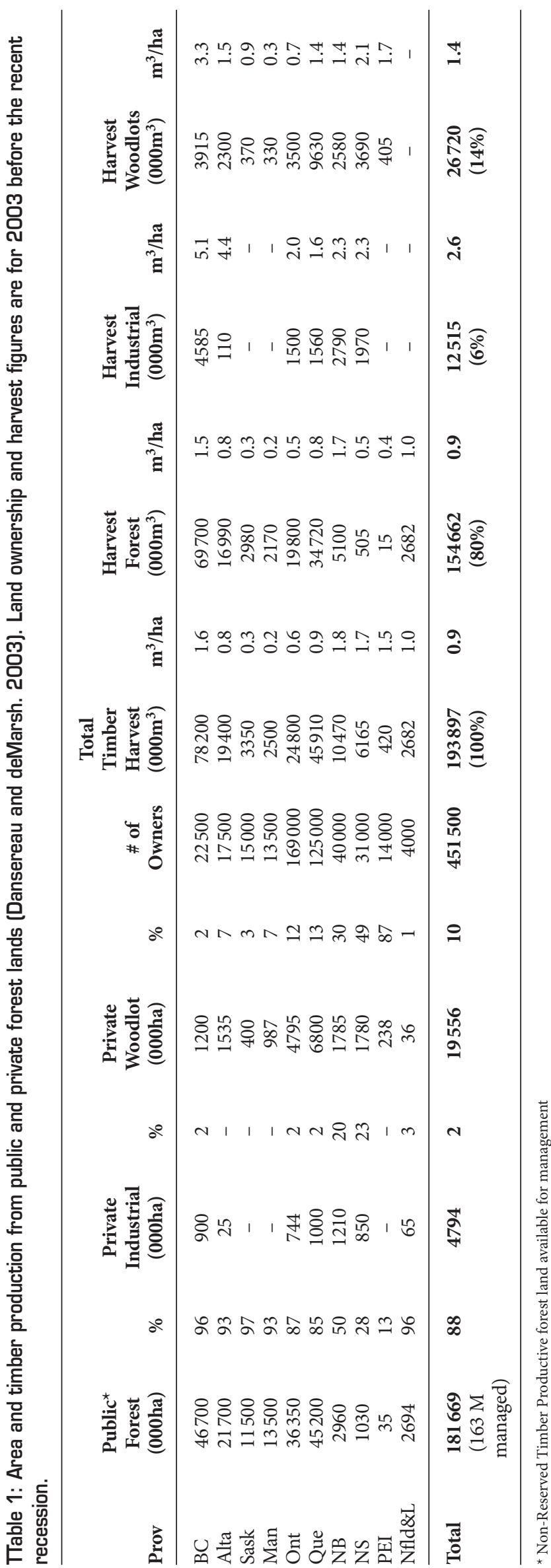




\section{Regional Distribution of Private Forest Land in Canada}

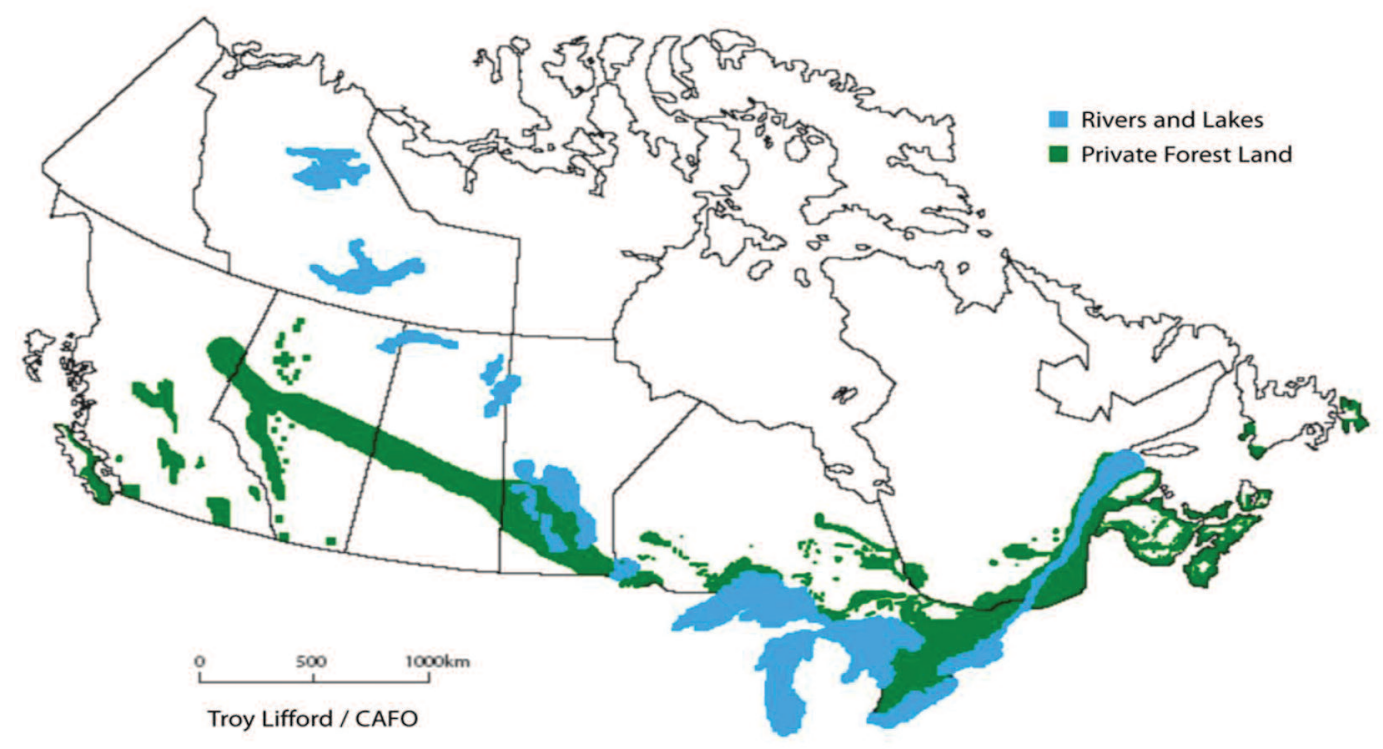

Fig. 1. The regional distribution of privately owned forest land follows the pattern of agricultural settlement and railway construction during the period 1700 to 1900.

are in the process of reverting to forest. In many cases, the old farms and woodlots are being sold to a new generation of landowners with an urban background who lack the skills, knowledge, and interest in maintaining timber production on these lands. Many of these new owners are more interested in conservation or recreation than timber production. This leads to a gradual transformation from a "Working Landscape" of farms and woodlots to a "Recreational Landscape". The new "Recreational Landscape" makes little or no direct economic contribution to the rural economy and therefore contributes to a decline in the level of rural prosperity and the stability of institutions in rural communities. This is not a benefit to the community or the nation.

\section{Area and productivity of privately owned forest land in each province}

Table 1 presents data on the area and timber productivity of the three categories of forest land (public, private industrial and woodlots) in each province. This information was drawn from the CCFM National Forestry Database maintained by the Canadian Forest Service. The data originates from provincial, federal and territorial forestry agencies. Both private woodlots and private industrial forest land produce more timber per ha than the more remote and northern publicly owned forest.

It is estimated that only $70 \%$ of the owners of private woodlots manage their woodlots for timber production. These private lands are capable of significantly higher production if more forest owners become active managers and timber producers. It is recognized that the property tax regime can influence land use. But little has been published about the variety of property tax regimes applied to private forest lands across Canada. These private forest lands make an important contribution to the national wood supply as well as providing the majority of the forest-related ecological goods and services (EG\&S) in the settled areas of Canada.

This report is based on a survey covering all ten provinces to find out about the various property tax regimes applied to privately owned forest land and the ways in which some provinces use the tax system to promote good forest management and responsible timber production. The report includes a few useful examples of taxation systems for municipalities and provinces interested in increasing the supply of timber to mills in rural areas and thereby improve rural prosperity. It is possible to provide a significant incentive through the property tax regime to encourage the owners to actively manage both agricultural lands and woodlots.

Harvest volumes from Private Industrial and Private Woodlots should be considered as quite different cases. In most cases private industrial forest land is a business asset belonging to a forest products company, a pension fund or independent investors. These lands are owned and managed primarily for timber production.

Private woodlots are owned by an estimated 450000 individuals with very diverse ownership and management objectives. It is believed that only $60-70 \%$ of woodlots are managed for timber production. The actual harvest per hectare is perhaps closer to $26720000 \mathrm{~m}^{3}$ produced from 13700000 ha $(70 \%$ of $19556000 \mathrm{ha})=1.9 \mathrm{~m}^{3} / \mathrm{ha}$ rather than $1.4 \mathrm{~m}^{3} / \mathrm{ha}$ as shown in Table 1. Foresters familiar with management of private woodlots estimate that the potential for growth and harvest is approximately $4 \mathrm{~m}^{3} / \mathrm{ha}$. These data are the best that are easily available. The CFS no longer publishes harvest data on the two categories of private land. Some provinces have better data on timber production from private lands than others. The author considers that these data provide a valid, if not pre- 
cise, indication of the areas of private forest land and the harvest of timber from forest land in both categories of private ownership and for publicly owned forest in the provinces across Canada. Public forest land includes lands owned by provincial, federal and territorial governments.Forest owned by counties and municipalities is considered to be private land.

\section{Provincial reports on the systems used to assess the value of privately owned forest land and levy property taxes}

\section{British Columbia \\ Setting and collecting taxes}

The BC Assessment office provides an assessment of the value of the land to Municipalities and to Regional governments. The Municipality sets the mil rate and collects taxes on lands within the boundaries of incorporated municipalities. Regional governments set the mil rate and collects taxes on lands outside incorporated municipalities.

\section{Land classification for taxation purposes}

There are several classes of land for assessment purposes, industrial, commercial, residential, and agricultural. Forest land falls into Class 7 for assessment purposes. Some forest land may also fall under residential or agricultural classifications depending on location and surrounding land use. There is also a Managed Forest Land category.

\section{How the tax rate is determined}

The value of most classes of land, including agricultural and residential land, is based on records of land sales. Values for Managed Forest Land are based on soil type, site characteristics, proximity to markets, and timber values. This process of analysis and valuation is carried out for each property. The tax is calculated using the mil rate set by the municipality or regional government. Property size does not affect the valuation or mil rate. Small unmanaged forested properties may be assessed for their residential value. If the property is actively managed, it should qualify for the Managed Forest tax rate. Lands classified as Managed Forest must meet the requirements of a "Management Commitment" as defined by the Private Managed Forest Land Act.

\section{Tax Incentives}

Many forested properties in BC are not within incorporated municipalities. The provincial government has jurisdiction over forest management and operations on all Managed Forest Land. Lands registered and managed under the provincial Managed Forest Program are under provincial forest management jurisdiction - not municipal jurisdiction. The assessed values are generally lower and school taxes are reduced.

\section{Programs to encourage active forest management}

The province does not offer technical assistance to forest landowners. Forest land that is registered under the Managed Forest Program benefits from lower taxes and must maintain the "Management Commitment" classification and comply with regulations. Failure to comply with these requirements may result in loss of Managed Forest status. Owners of Managed Forest land must also file an annual report on all forest management activities, but are not obligated to harvest wood. All areas on the Managed Forest property that are not covered by forest or have been cleared during harvesting operations must be regenerated within a specified time period.

The incentive offered by lower property and school tax rates and having forest management activities regulated by the province rather than the local municipality are important. Low taxes help to ensure that land remains under forest cover and is not cleared for some other land use. Low taxes also provide an incentive (but no legal obligation) to harvest wood and make a contribution to the regional economy.

Provided that the landowner maintains Managed Forest status for a period of 15 years there is no penalty for withdrawal from the program. Land withdrawn from the program after a period of less than 15 years will incur a graduated penalty.

\section{Alberta}

\section{Setting and collecting taxes}

Municipal governments set and collect taxes on forested land.

\section{Land Classification for taxation purposes}

Forested land is classified as 'agricultural' where a woodlot is part of a larger property used for agriculture, or as 'highest and best use.' Forested land may also be classified as 'residential' even if there is no house on the property. Woodlot management is not recognized as an agricultural use. Growing Christmas trees is classified as an agricultural use. Forested land used for recreational purposes is gradually being transferred from classification as agricultural land to a higher tax designation.

\section{How the tax rate is determined}

The assessed value of the land is based on market value. The tax rate on agricultural land is based on the productive capability of the land - pasture, hay, grain - using soil type, topography and other factors. The rate of tax on forested land is set by the municipality using the assessed value and a mil rate. The tax rate is not affected by the size of the propertybut the market value per hectare may be affected by the size of the property. It is not unusual for large properties to sell for less per hectare than smaller properties.

- The tax rate varies depending on the assessed value of the land. The rate does not depend on whether the forested land is managed for timber production land or is unmanaged. Consideration is being given to recognizing the difference between managed and timber productive land and unmanaged (recreational) land but no formal decision and action have yet been taken to do this.

- Remote sensing is increasingly used to provide indications of land use. Parcels with evidence of agricultural operations are usually classified as agricultural.

\section{Tax incentives}

The province does not offer tax incentive programs to encourage active forest management and timber production.

\section{Programs to encourage active forest management}

The province does not offer other programs to encourage active forest management and timber production. 


\section{Saskatchewan}

Setting and collecting taxes

The rate of tax is set by the municipal mil rate and collected by the municipality.

\section{Land classification for taxation purposes}

There is no specific land classification for forested land. Land that has not been cleared or has reverted to forest is often classed as bush pasture and taxed as non-arable pasture land. Tree cover reduces the production of forage for livestock and a tax adjustment is made for areas covered with aspen, conifers or brush.

\section{How the tax rate is determined}

Agricultural land is classed as regulated land. The value is set by regulation and not assessed at market value. There are two categories of agricultural land:

- Non-Arable land (range/pasture) and,

- Other Agricultural land (cultivated)

The assessed value of regulated land is determined by the present use of the land. Wetlands may be assessed as having no (agricultural) use and therefore no value for tax purposes. Forested land is considered to be non-arable land and is taxed at a very low level. This might be considered to be a tax incentive to keep the land in forest.

\section{Tax incentives}

There are no explicit incentives within the property tax system to encourage private land forest management.

\section{Programs to encourage active forest management}

There appear to be no programs offered to promote or assist forest management on private lands.

\section{Manitoba}

\section{Setting and collecting taxes}

Municipal governments set and collect taxes on forested land.

\section{Land classification for taxation purposes}

Land classification is based first on use and second on zoning. If the land has a cottage and is used as a weekend residence it is classed as rural residential. If there is no residential structure it is classified according to the municipal zoning regulations which in rural areas, is usually farm land.

\section{How the tax rate is determined}

The tax is based on the assessed value of the land using sales of comparable properties. The market value is multiplied by a factor ( 0.45 for residential properties and) ( 0.26 for farm properties). This provides a "portioned assessment" which is applied against the mil rate to calculate municipal and school taxes.

- As noted above the tax rate does vary depending on the classification of the land-rural residential or farm. The tax rate does not vary based on whether the forested land is actively managed or unmanaged.

\section{Tax incentives}

The province does not offer tax incentives to encourage active management and timber production.
Programs to encourage active forest management

The Private Land Resource Planning program of the Manitoba Forestry Association offers a range of technical assistance to private forest land owners. These include the preparation of woodlot management plans, logging planning, wood measurement and tree planting. Some of these are offered on a "fee for service" basis.

\section{Ontario}

Setting and collecting taxes

Municipal and regional governments set and collect taxes on forested land.

\section{Land classification for taxation purposes}

Ontario has seven land tax classes. This provides flexibility to vary the rate of tax on land. The seven classes are: industrial, commercial, multi-residential, residential, pipelines, farm and managed forest. Forest land owned by registered farmers is classed as farm land. These are taxed at $25 \%$ of the general tax rate. Forest lands included in the Managed Forest Tax Incentive Program (MFTIP) are also taxed at 25\%. All other forested lands are classed as residential or another class if appropriate and taxed at $100 \%$ of the general tax rate based on current use.

\section{How the tax rate is determined}

The assessed market value of the property is determined by a provincial organization - The Municipal Property Assessment Corporation.

- Farm land is assessed on the basis of sales of farm land of various soil productivity classes. Managed forest land is assessed at the same rate as woodlots on farms and is based on farm land sales and soil productivity classes. Land legally designated as Conservation land is exempt from taxation.

- Land values are revised on a 4-year cycle based on sales records. The Assessment Review Board hears complaints about land valuations.

- The level of tax is not based on the size of the property. The market value per hectare might be influenced by larger properties selling for a lower price per hectare.

- The tax on forested land is reduced for lands that qualify for inclusion in the Managed Forest Tax Incentive Program (MFTIP). A 10-year management plan approved by a provincially qualified managed forest plan approver (MFPA) is required. The MFTIP program includes a variety of management objectives from wildlife habitat improvement to timber production. The plan will be based on the forest landowner's objectives and the landowner agrees to manage towards the objectives listed in the plan and to carry out all management operations in accord with good forest practices as defined in the Forestry Act. Active management for timber production is not required. Forested land that is part of a registered farm operation benefits from the $25 \%$ tax rate but does not have to be covered by a management plan and included in the MFTIP program. 


\section{Tax incentives}

The province provides a low tax rate for forested land included in the MFTIP. The minimum property size eligible for the MFTIP is 4.0 ha. There is no upper limit to the size of property eligible for inclusion in the MFTIP. The property must be owned by a Canadian: resident, entity or corporation and covered by a specified density of tree cover. The MFTIPapproved plan will be designed to achieve the landowner's objectives. The program recognizes a wide range of objectives - timber production, climate change mitigation, wildlife conservation. Reporting on all operations/activities is required at year 5 and year 10. The plan must be renewed at 10 -year intervals. The MFTIP does not include technical assistance. The MFTIP program provides an incentive to maintain land in forest cover but does not provide a specific incentive to grow and harvest timber.

\section{Programs to encourage forest management}

Ontario has a 50-Million Tree Program that provides financial incentives to plant trees on idle land. The incentive covers about $70 \%$ of the costs.

\section{Quebec}

\section{Setting and collecting taxes}

Property evaluation for purposes of taxation is carried out by licensed evaluators employed by municipalities, regional county governments (MRCs) or consultants employed specifically for this purpose. The assessed value is reported to the municipality and a mil rate set by the municipal council is applied to calculate the property tax due. School taxes are also based on this evaluation but the mil rate is set by the local English or French school board depending on the choice/affiliation of the landowner.

\section{Land classification for taxation purposes}

There is no specific land classification for forested land. Most municipalities use six land use classes for taxation purposes. A different mil rate is usually applied to each land use class: 1. industrial; 2. commercial; 3. multi-residential (minimum six units); 4. residential; 5. vacant serviced lots; and, 6. agricultural and forested land. Land under legal protection as 'Conservation Land' under the provincial "Reserve Naturel" program will qualify for exemption from school taxes and a reduction in municipal property taxes.

\section{How the tax rate is determined}

The tax rate is a combination of the assessed value of the land and the mil rate applied by the municipality. The tax rate is not affected by the size of the property though the assessed value per hectare is affected by property size-as in other provinces, larger properties generally sell for a lower price per hectare than small properties. There is no special tax category for managed forest land, and therefore no requirements to qualify for a managed forest land tax rate nor any verification process.

\section{Tax incentives}

There is no specific land classification for forested land and there are no specific incentives built into the general property tax system to encourage the active management of private forest land. However, the province has a comprehensive program of forest management incentives available to forest landowners, including a rebate of up to $85 \%$ in annual property taxes (municipal and school) paid on land (not buildings) if the total eligible expenses for forest management work exceeds the total property tax paid. This reimbursement of property taxes is paid as a deduction on the landowner's provincial income tax but it is, itself, treated as income and is thus subject to income tax the subsequent year. The program is described below.

\section{Programs to encourage active forest management}

The provincial government's Financial Assistance Program for the Development of Private Woodlots, in place since the mid-1980s, provides direct financial assistance (subsidies) for specific phases of forest management work, provided that these meet detailed technical criteria. It is complementary to the Real Estate Tax Reimbursement Program for Certified Forest Producers in that particular forest management treatments and activities can benefit from one or the other (not both) of these programs. Both programs include: preparation of forest management plans, annual visits by a forester or technician, a wide range of silvicultural treatments including site preparation, planting, tending, thinning, partial cuts and forest access road construction, and maintenance, including bridges and culverts. To qualify for financial assistance through either of these programs, landowners must own more than four hectares of forest land, have a forest management plan prepared by an accredited consulting forester and registered with the provincial government. They thereby obtain the official status of "Forest Producer". Technical aspects of forest management work carried out as part of the woodlot management plan must be planned, approved, and verified by the consulting forester.

\section{New Brunswick \\ Setting and collecting taxes}

Taxes are set by the provincial government and collected by municipalities, Local Service Districts and the provincial government, depending on the location of the property and which organization provides services (e.g., road access and maintenance) to the land.

\section{Land classification for taxation purposes}

Forest land may fall into several categories for taxation purposes. It depends on the size, location, ownership, and use of the land. The categories are: forest land, vacant land, timberland, recreational land, freehold timberlands, and residentialif close to houses. Some large properties may fall into a combination of these classes.

\section{How the tax rate is determined}

The tax rate is based on the value of the land as assessed by the provincial government office responsible for valuation GeoNB and Service New Brunswick. The assessed value is not directly based on land sales. In the case of woodlots, the value is set by the government at approximately $\$ 100 /$ hectare with a tax rate of approximately $\$ 1.70 / \$ 100$. The tax rate is generally independent of the size of the property and its management. 


\section{Tax incentives}

The low rate of tax on forested land provides an incentive to keep the land in forest and to manage it.

\section{Programs to encourage active forest management}

The province does provide financial assistance for silvicultural programs (site preparation, planting and tending) on woodlots. These programs are delivered through the regional wood marketing boards. There is a low tax rate on forested land but no specific tax-based incentives to encourage timber growth and harvesting. The low tax rate does provide an incentive to keep land in forest. There have been discussions about some tax-based incentives to encourage the growth and harvest of timber but, as the present tax level is quite low, an upwards adjustment would have to be made on lands that are not actively managed to create an incentive for active management and timber production.

\section{Prince Edward Island}

Setting and collecting taxes

The tax rate is set by the province and municipal governments. Fire Districts may set fire protection charges in addition to the property tax. Taxes are collected by the province or municipality.

\section{Land classification for taxation purposes}

Forested land is classified as forest land. Tax is based on the assessed value of the land. The value is set by the property assessment staff of the provincial government and is based on sales records. The size of the property is not a factor except as it may be reflected in the market value. There is no managed forest category.

\section{The tax rate}

The tax rate is set by the municipality. It does not depend on whether the property is actively managed or not.

\section{Tax incentives}

The province does not offer property tax incentives to encourage active management and harvesting.

\section{Programs to encourage active forest management}

The province has programs to support management. These include forest management plan development (Forest Enhancement Program) and a lending program (Forest Investment Program) to implement silvicultural treatments included in an approved plan. The availability of loans might be considered as enabling, rather than encouraging, active management.

\section{Nova Scotia}

\section{Setting and collecting taxes}

The classification and valuation of land for tax purposes is done by the Property Valuation Services Corporation of Nova Scotia. The tax rate is set and taxes are collected by each municipality. "Eligible" forest land is subject to a flat tax as set out in the Municipal Government Act.

\section{Forest land classification for taxation purposes}

Bona fide managed and productive forested land is classified as Resource Land or Commercial Land depending on the size of the property and is "eligible" for the flat tax rate. If there is evidence that forested land is not used for forestry the land might be classified as recreational, vacant residential or vacant commercial. These land classifications are taxed at market value. Agricultural land, conservation land and lands owned by certain charities or public bodies are exempt from property tax. Municipalities receive grants in lieu of taxes from the provincial government to compensate for these exemptions.

\section{How the tax rate is determined}

A flat tax per hectare is paid to municipalities as set out in the Municipal Government Act. The tax rate is determined by the size of ownership.

- For owners controlling less than 20243 ha the land is classified as Resource Land and is taxed at a rate of $\$ 0.62 /$ ha if the municipality has a fire protection charge.

- For owners controlling more than 20243 ha the land is classified as Commercial Land and is taxed at a rate of $\$ 1.00 /$ ha.

- To qualify for and maintain the Resource or Commercial Land classification the owner may be required to complete and file a Statement of Property Use with the provincial assessors. There is an appeals process.

- As part of the Statement of Property Use, owners of Resource or Commercial lands may be required to have: a management plan, records of actual timber production, and records of tree planting to support their claim to Resource or Commercial Land tax status. The reduction in property taxes due to classification as Resource or Commercial Land is significant.

- If all or a portion of the forest land that has benefited from the low tax rate granted to Resource and Commercial land ceases to be used for forestry purposes, the owner/person responsible for the change will be subject to a "change in use" tax determined by the assessor. The "change in use" tax is equal to $20 \%$ of the assessed value of the land that has undergone the change of use.

- The low tax rate levied on Resource and Commercial forest lands is designed to maintain these lands in forest and under management. If management ceases there will be a significant increase in annual property taxes as well as the one-time "change in use" tax.

- The low tax rate for Resource and Commercial forest lands also recognizes that it is the presence of buildings and the activities of people that drive the cost of municipal services, not the presence of forests.

- Forested land may qualify for classification as a Conservation Property and be exempt from all taxation. Significant ecological value and permanent legal protection is required to qualify. The provisions of the Conservation Easement Act, the Special Places Act or the Wilderness Areas Protection Act apply.

\section{Tax incentives}

The low property tax rates noted above provide an effective incentive to keep land in forest and under management. 


\section{Programs to encourage active forest management}

The province offers technical assistance and funding for silvicultural treatments to forest owners. The province also gives financial support to landowners' organizations that provide technical and management services to forest landowners.

\section{Newfoundland and Labrador \\ Setting and collecting taxes}

The provincial government sets the tax rate and collects the provincial tax on forest land.

\section{Land classification for taxation purposes}

Forest land is classed as forest land.

\section{How the tax rate is determined}

The tax is set at a fixed rate per hectare by the Forest Agency. The tax rate does not vary depending on the size of the property but does depend on whether the land is actively managed or not.

- The tax on managed forest land is calculated by multiplying the managed and productive area of the property, exclusive of water bodies greater than two ha in area, by the annual tax rate approved by the Lt. Governor-inCouncil.

- For forest land that is not managed, the tax rate is based on a percentage of the market value of the land.

- The rate varies depending on the length of time that the land has not been managed. If for 1 year-5\% of the market value. If 2 years $-10 \%$ of the market value. If the land is not managed for three or more consecutive years the tax is set at $20 \%$ of the market value.

- Management of the land is determined by the existence and active implementation of a management plan.

- There is a requirement to file an annual report on management activities.

\section{Tax incentives}

There are no tax incentives to encourage active forest management other than the significant increase in the tax rate on land that is not managed (see above).

\section{Programs to encourage active forest management}

Less than $4 \%$ of the forest land is privately owned. Harvesting on forest properties larger than 120 ha requires a management plan approved by the government before harvesting takes place. Only three landowners have forested properties larger than 120 ha. This land represents less than $1 \%$ of the forest land in the province.

\section{Comments}

Several decades ago a report produced for the government of Nova Scotia noted that it is the activities of people and presence of buildings that drive the demand for municipal services and incur expenses for policing, fire protection, garbage collection and most other aspects of municipal administration. People and buildings should logically bear the majority of the tax load. Land does need road access. The municipal rural road system that provides access to rural lands requires summer and winter maintenance but the land itself incurs few other municipal expenses. It is in the long-term interests of rural communities that agricultural land be well-managed and remains in production and that forest land is managed to maintain the forest in a healthy condition and produce forest-related EG\&S as well as timber to support the rural economy. A well-designed property tax structure that is accepted as fair and is supported by taxpayers can help to achieve these objectives.

Forest-related EG\&S are: habitat for forest-dependent wildlife, water quality conservation, regulation/moderation of runoff in watersheds and landscape aesthetics. Forest landowners have long maintained that their contribution of forest-related EG\&S enjoyed by the public should be recognized by lower tax rates on forest land. The public should not enjoy free benefits from the EG\&S provided by the owners of private forest lands.

Property tax rates offer a tool to encourage the active management of forested land and the production of timber. Most people respond well to incentives. Incentives are seldom seen as an infringement on property rights. Stern regulation directed at achieving the same objectives will generally be resisted. It is possible that the provision of incentives is a more efficient way to achieve land management objectives than by regulation-which requires administration, inspection and enforcement. People voluntarily seek to benefit from incentives.

All provinces should recognize the potential of privately owned forested land to make a contribution to rural prosperity and provide incentives to encourage active management. Property tax rates that encourage active forest land management, coupled with provincial tree planting programs can expedite the reforestation of fields and pasture that are no longer used for agriculture. These plantations will start to make a contribution to the local wood supply and to the rural economy after about 30-35 years of growth. Allowing Nature to take its course and relying on natural regeneration to reforest the idle fields and pastures may take $70-100$ years before the new forest is capable of making a contribution to the local economy.

In most provinces agricultural and forested lands benefit from lower tax rates. This is logical as these lands do not cause significant expense to municipal governments. In the same way that a low level of tax on agricultural land is designed to support the continuation of farming activities, low taxes on forested land can be designed to promote good management, growth and harvesting of timber to support the rural economy and community prosperity.

Rural lands should be taxed based on the actual use of the land, not some hypothetical use proposed by the local assessors or zoning. Taxation of forest land based on potential forest growth and timber yield has been recognized as an approach that is complicated and expensive to establish with fairness to all landowners. A more practical approach is a tax based on land values but with a mil rate based on actual land use and the cost of municipal services provided to the land. An attractive rate of property tax on managed forest land provides landowners with a reason to keep the land in forest and provides an incentive to produce timber with benefits to the rural economy.

It should be emphasized that private forest land provides the majority of the forest-related ecological goods and services (EG\&S) in the settled regions of Canada. The general public benefits from the forest-related EG\&S provided by and 
paid for by the landowners. If the forest land and woodland operations are well-managed and economically viable, the community can also benefit from the economic contribution to the rural economy from timber production without loss of the environmental benefits. If the community provides a financial benefit to forest land owners through low property taxes, it is reasonable to expect that the landowners should support the rural economy in return by management of the land to ensure a healthy productive forest and timber production. It is also reasonable to expect that management operations on these forest lands will conform to the expectations of society.

Owners of forested land who benefit from a low tax rate that provides an incentive for good management and timber production should consider that they are engaging in a longterm 2-part "social contract" with the community. The lower the tax, the more binding the social contract will be.

The "social contract" would be:

- For the landowner: Low taxes, without excessive restrictions on land use or administrative burden to obtain management permits; and,

- For the community: The continuing presence of forestbased EG\&S and wood production to contribute to community prosperity.

In the event that the forest landowner decides to change the use of the land, the case for charging a one-time "Change in Use" tax is persuasive (see Nova Scotia). A unilateral increase in the tax rate levied by the municipality will also damage the contract. Incentives built into the tax system offer a more efficient way to gain the participation of landowners than stern regulation.

\section{Recommendations}

Landscape contributions to community prosperity

- Working landscapes provide economic support and contribute to rural prosperity and the stability of community institutions. These contributions should be encouraged and rewarded by low property taxes.

- Recreational landscapes can provide support to rural communities through the payment of higher taxes.

- The recreation and tourism sector should not be "free riders" on the forest-related EG\&S provided by taxpaying forest landowners.

Provinces and/or rural municipalities might consider the establishment of three rural land tax categories.

- Residential property-houses, buildings and 2-4 ha of land-standard residential tax rates.
- Unmanaged land or land used for personal recreation with tax rates that recognize the contribution of EG\&S - moderate tax rates.

- Managed productive land with a low tax rate as an incentive to actively manage and produce agricultural products, forest-related EG\&S and timber.

Managed productive land might be defined as:

- Land that is in agricultural production-cultivated arable land, hay fields with regular harvest and pasture land with regular grazing.

- Forest land that is managed, with a program of timber harvesting or production of commercial non-timber forest products-e.g., maple syrup.

- Land on which agriculture has been discontinued and the cleared land has been planted with trees. Financial assistance to defray the costs of planting trees on idle/marginal/sub-marginal agricultural land is justified by the long period of growth (30-35 years, a generation) before the landowner can expect revenues from timber harvest.

Unmanaged land or land used for personal Recreation is idle and not productive. There is also land that is not suitable for management and production-high elevation, rocky, steep, wetlands. These lands do not fall into either categoryManaged Productive or Unmanaged or Recreational. An equitable approach to the taxation of these lands is needed. Landowners can consider the tax rates and benefits accruing from each land use and choose which course they wish to follow. It is not good management to allow land to remain in an un-managed and non-productive state on a vast scale across this country. We sacrifice too much potential contribution to rural employment and national prosperity when such valuable assets are allowed to lie idle for decades.

\section{References}

Dansereau, J-P. and P. deMarsh. 2003. A portrait of Canadian Woodlot Owners in 2003. Forest. Chron. 79(4).

[Note to the reader: I am indebted to the people across the country who provided information on the property tax systems used by each province. In some cases it is quite complicated. We have done our best to be brief and correct. I take full responsibility for the opinions expressed in all other sections of this report.] 